\title{
ECONOMIC IMPACTS OF THE ORGANIZATION OF BIG SPORTS EVENTS BASED ON THE EXAMPLE OF THE EUROPEAN LASER SENIOR CHAMPIONSHIP 2014
}

\author{
Alen Jerkunica, Toni Miljak, Majda Todorović \\ University College of Management and Design Aspira, Split, Croatia
}

\begin{abstract}
Background. Tourism and sport, apart from being a significant social phenomenon, are close to each other and interfere. In modern society, sport has become an important content during a tourist's stay in a destination, regardless of whether he/she is an active participant in competitive or recreational sports activities. Tourism industry has a share of $18.2 \%$ of GDP of the Republic of Croatia, but seasonality is one of the key problems. The modern tourist should be offered added value such as excursions, sports or musical events, cultural manifestations, etc. The stated values can be achieved with a proper destination management. Aim of the research was to demonstrate on the example of the organisation of a big sports event, how and to what extent a big sports event affects the increase of consumption in a destination.

Methods. The research employed a questionnaire survey.

Results. Guests, participants of the big sports event spent more than the average tourist in the destination on the annual level.

Conclusions. The organization of a big sports event has a number of positive consequences for the economy of a destination. In addition to the fact that guests and participants of big sports events spend more than an average tourist in a destination does per day, they want to learn about the history and culture and other attractions in a destination they visit or stay. The above mentioned has the effect of getting a positive impression that they will transfer to their families and friends who will also want to visit the destination. Also, the organization of a big sports event in the preseason or postseason contributes to the extension of the tourist season, which is extremely important for the city of Split since tourism is still seasonally oriented despite the fact that it has a high 18.2\% of the GDP (in 2016 and $17.2 \%$ in 2014).
\end{abstract}

Keywords: big sports event, consumption, income of the destination, sports tourism.

\section{INTRODUCTION}

$\mathrm{W}$ hen it comes to tourism, it can be said that tourism is a socio-economic phenomenon based on people's needs for a temporary change of their residence of work, rest and entertainment as well as possibilities to satisfy those needs. It is the key support of total long lasting Croatian developing strategy, and it is based on natural and transportation resources and human capital.

Tourism plays two main roles (Bartoluci \& Škorić, 2009.):

- a balance-of-payments stabilizer,
- a stabilizer of the national labour market.

Tourism has to help balance economic relation of the domestic economy with the international one. Furthermore, tourism can decrease the unemployment rate by employing new people in tourism sector. The economic crisis as well as a downward trend in the world and domestic market has increased the number of the unemployed in the Republic of Croatia in the period between 2005 and 2013. According to the Croatian Employment Service, the average unemployment rate in 2005 was $8.6 \%$, and in 2013 it was $20.2 \%$ (Hrvatski 
zavod za zapošljavanje - Godišnjak 2013, 2014). After 2013, a decrease in the number of unemployed was noted, which is a consequence of coming out of economic crisis.

It is important to emphasize that tourism is the only economic activity, which continuously marks positive results even during the time of economic crisis. In 2013, the number of tourist arrivals increased by $5.1 \%$, and the number of overnight stays by $3.3 \%$. Such movement is the result of a positive trend of foreign tourist overnights, since in the last two years a downward trend has been marked in the number of domestic tourist overnights. The share of foreign tourists in the total number of arrivals was $88.1 \%, 92.1 \%$ of overnights if compared to $11.9 \%$ of arrivals and $7.9 \%$ of overnights of domestic tourists (Hrvatski turizam u brojkama, 2014).

The term sports-oriented travel is more commonly encountered on the tourist market (UNWTO, 2013). Tourism, sport and sport recreation interfere, which is reflected in their multifunctionality. Competitive sports tourism implies all travels for participation in certain sport competitions, from domestic to international ones. Participants of this form of sports tourism are athletes, coaches, auxiliary staff and viewers of sports events, especially the media (Bartoluci, Škorić, \& Šindilj, 2013). Numerous sports events extend the offer of a certain destination, thus strengthening its competitiveness. When organising a sports event, the offer of activities connected to a certain event should be modified according to specific demands in order to gain quality (Beech \& Chadwick, 2004). In the period between $7^{\text {th }}$ and $14^{\text {th }}$ June, 2014, the European Laser Senior Championship (the Championship) was held in Split. It was organised by the Sailing Club Split and more than 300 people participated in the Championship. The organization of a big sports event helps to attract a large number of tourists. By attracting a larger number of tourists, the consumption in the destination increases, resulting in an increase in the revenue of the destination.

Tourism in Croatia. The stated data show the importance of tourism industry for the economy of Croatia. Thus, analysing the data for the last couple of years, a continuous growth has been recorded in the number of tourist arrivals and overnights, and in tourist revenue. In 2013, tourist revenue was $€ 7.18$ billion, and it represented a share of $16.5 \%$ of GDP in the Republic of Croatia. There were 12.45 million of tourist arrivals. The year 2014 marked a rise of 600,000 of tourist arrivals if compared to the previous year. Tourist revenue amounted to $€ 7.4$ billion, while a tourism share represented $17.2 \%$ of GDP (Statistička analiza turističkog prometa u 2014. godini, 2015). In 2016, a tourism share was $18.2 \%$ of GDP. In the same year, there were 78 million overnights or $9 \%$ more than the previous year. Foreign tourist overnights marked a rise of $9.6 \%$, and domestic tourist overnights marked a rise of $2.0 \%$.

During 2013, Croatian tourism proved its market activity. The results of the tourist season were above every expectation. According to the figures, in the first ten months, 12.1 million tourists visited Croatia or 5\% more if compared to the same period of the previous year, and it reached 71 million overnight stays, or 4\% more than in 2012. An upward trend of tourist trade was marked in all Croatian counties, and Croatia in the first ten months achieved results better than expected. The total rise of the first ten months was mostly marked by foreign tourist arrivals, which amounted to 10.98 million or $6 \%$ more compared to the same period the year before, and a rise of 5\% was reached in overnight stays with 65.1 million of overnight stays. Domestic tourists achieved the results similar to the previous year's results, with more than 1.1 million arrivals, they got the identical number of arrivals, whereas, a $2 \%$ decrease was noted in the number of overnights (Statistička analiza turističkog prometa u 2014. godini, 2015).

The average tourist consumption. In 2010, the Institute for Tourism conducted the research on tourist consumption in Croatia, which is relevant for the comparison of the results of participants in the European Laser Senior Championship (Stavovi i potrošnja turista u Hrvatskoj - TOMAS 2010).

According to the results of the mentioned research, the average expenditures of a tourist per day were $€ 58$ on the state level, and $€ 55$ on the level of Split-Dalmatia county (the County), whereas the average daily expenditures reached the amount of $€ 121.1$ throughout the area of Split. The average daily expenditure refers to accommodation service, food and costs of other services (shopping, sport and recreation, culture, entertainment, trips and similar).

The study of 2010 shows that $74 \%$ of average daily consumption refers to hospitality service and the rest represents the costs of other services. 
Table 1. Tourists and overnights by counties (the period from January to October 2013)

\begin{tabular}{|l|r|c|c|c|}
\hline \multirow{2}{*}{ REPUBLIC OF CROATIA - TOTAL } & \multicolumn{2}{|c|}{ Tourists } & \multicolumn{2}{c|}{ Overnights } \\
\cline { 2 - 5 } & Total & Index 13/12 & Total & Index 13/12 \\
\hline & 12132165 & 105 & 71252456 & 104 \\
\cline { 2 - 5 } & \multicolumn{2}{|c|}{ Tourists } & \multicolumn{2}{c|}{ Overnights } \\
\hline ISTRIA COUNTY & 3142022 & 101 & 21875229 & 100 \\
\hline PRIMORJE-GORSKI KOTAR COUNTY & 2223191 & 102 & 12477203 & 102 \\
\hline LIKA-SENJ COUNTY & 480136 & 105 & 1927418 & 107 \\
\hline ŠIBENIK-KNIN COUNTY & 1347378 & 107 & 9552025 & 104 \\
\hline SPLIT-DALMATIA COUNTY & 815752 & 107 & 5346590 & 107 \\
\hline DUBROVNIK-NERETVA COUNTY & 2149462 & 110 & 12705855 & 108 \\
\hline CITY OF ZAGREB & 1264143 & 109 & 6155700 & 107 \\
\hline
\end{tabular}

Source: Tourist Board of the Split-Dalmatia County.

Talking about segments of average consumption, the following can be said:

- $49 \%$ of the average daily consumption represents accommodation service, which is $€ 28.62$ for accommodation service on the state level, and $€ 26.95$ on the County level, and $€ 59.34$ on the Split level;

- $9 \%$ of the average daily consumption refers to other food service within accommodation service, which is $€ 5.27$ on the state level, $€ 4.95$ on the County level and $€ 10.90$ on the Split level;

- $16 \%$ of the average daily consumption refers to other services of food and beverages outside accommodation service, which is $€ 9.34$ on the state level, $€ 8.80$ on the County level, and $€ 19,38$ on the Split level;

- $26 \%$ of the average daily consumption refers to costs of other services, which is $€ 15.18$ on the state level, $€ 14.30$ on the County level and $€ 31.49$ on the Split level.

Destination. When tourism is concerned, it is important to state that a modern tourist wants not only the sun and sea but also other facilities. $\mathrm{He} / \mathrm{she}$ wants to learn about local culture, meet local people, national folklore, gastronomy, visit festivals, sport tournaments, museums, galleries, etc. By implementing the Tourism Development Strategy of the Republic of Croatia by 2020 (Strategija razvoja turizma Republike Hrvatske do 2020. godine, 2015), the Government of Croatia has pointed at disadvantages of destination management with the aim of satisfying the needs of a modern guest. Managing a destination is an integrated process of managing the key elements of the tourism mix, marketing communication, mediation, and destination partnership. The basic intention is to increase the number of arrivals balancing tourism demand and offer. Tourist Boards are in charge of the destination management.

Tourism and Destination Management Organisation can be defined as a process of shaping, managing and developing tourism system, public offer and interest in a destination (Magaš, 2003). All developed tourist destinations search for new content in order to enrich their offer. There are two trends in the world. One leads to a trend of preserving historical monuments, culture and nature or authentic heritage. The other is directed toward newly formed attractions. However, as time passes, those attractions become part of physical, historical and cultural environment they become "natural". This process obscures the difference between them; therefore, it is difficult to differ between natural attraction with the elements of newly formed attraction and newly formed attraction that soon integrates in its natural environment (Butler \& Pearce, 1995). Other attractions, such as sport competitions and music festivals have also developed.

A positive trend of branding and developing a destination is definitely the city of Split, which has lately transformed from a transitional into a tourist city. In order to keep guests more than just for sightseeing, within already existing events like the traditional Split Summer Festival, new events 
have been created such as the Days of Diocletian, Summer Colours of Split, etc. Moreover, Split has become the host of the Ultra Europe Festival, a festival of electronic music for a minimum period of five years. Over 120,000 guests from more than 100 counties worldwide visit the festival in three days of its duration.

The European laser senior championship. As stated in the title of this article, the aim of this work was to research social and economic impacts which the Championship had. In order to present the hypothesis $\mathrm{H} 1$, the relation of the statistical data on the average consumption of a tourist inside and outside the city of Split should take into consideration, as well as, the relation of the stated figures if compared to the average percentage for the County and the Republic of Croatia.

$\mathrm{H} 1=$ Championship participants have higher expenses than the average expenditures of a tourist on the Split level

H1.1 = Championship participants have higher expenses than the average expenditures of a tourist on the Split-Dalmatia County level

H1.2 = Championship participants have higher expenses than the average expenditures of a tourist on the level of the Republic of Croatia It is assumed that Championship participants want to explore the city as well as surrounding destinations more, thus the following hypothesiswas formed:

$\mathrm{H} 2$ = Championship participants wish to find out more about history and culture, and other sights of a destination where they stay.

Moreover, it is assumed that Championship participants spend less on souvenirs, tourist attractions and the similar than an average guest who visits Split, the County or Croatia, therefore, the following hypotheses have been formed:

H3 = Championship participants have lower expenses than the average expenditures of a guest on the Split level for other services (souvenirs, tourist attraction tours and similar) H3.1. = Championship participants have lower expenses than the average expenditures of a guest on the County level for other services (souvenirs, tourist attraction tours and similar) H3.2. = Championship participants have lower expenses than the average expenditures of a guest on the state level for other services (souvenirs, tourist attraction tours and similar)

\section{METHODS}

The empirical research was conducted during the Championship on the chosen group of participants. The surveyed group included competitors, coaches, clubs and organisation representatives, sponsors and spectators. The research was conducted employing a questionnaire, which was composed of 17 questions divided into two parts. In the first part, respondents were supposed to answer the questions about their gender, age, country of origin, their role in the Championship, their average monthly income. The second part of the questionnaire was composed of questions concerning their visit to Split, whether it was their first visit to Split, if they had information about it prior to their arrival, where they stayed, whether they planned to visit other cultural events, manifestations and similar, the costs of their stay and the amount they planned to spend on other hospitality services, souvenirs, trips, tourist attractions and the similar during their stay in Split.

\section{RESULTS}

In total, 204 questionnaires were correctly completed. If analysed according to gender, $65 \%$ of respondents were men (133), whereas $35 \%$ of them were women (71). The majority of respondents, more precisely $51.97 \%$ or 106 , were from countries that are part of the European Union (Croatia excluded); $12.25 \%$ of the total number of respondents were from Croatia.

If the total number of respondents is considered, 150 of them were competitors and they represented a $73.52 \%$ segment. There were 29 coaches, or $14.22 \%, 11$ associates from organisations $(5.39 \%)$, three sponsors $(1.47 \%)$, six spectators $(2.94 \%)$, whereas 5 respondents did not state their status.

If we consider the economic aspect of the Championship, the questionnaire had a particular number of economic questions.

When asked who paid for accommodation service, 71 respondents $(34.80 \%)$ answered that travel and accommodation expenses were covered by their main club or organisation; 29 respondents $(14.22 \%)$ answered that expenses were covered by the sponsors, whereas 59 respondents claimed that travel and accommodation expenses were paid by themselves. As far as other respondents were concerned, 24 of them had more sources 
Figure 1. The number of competitors by countries

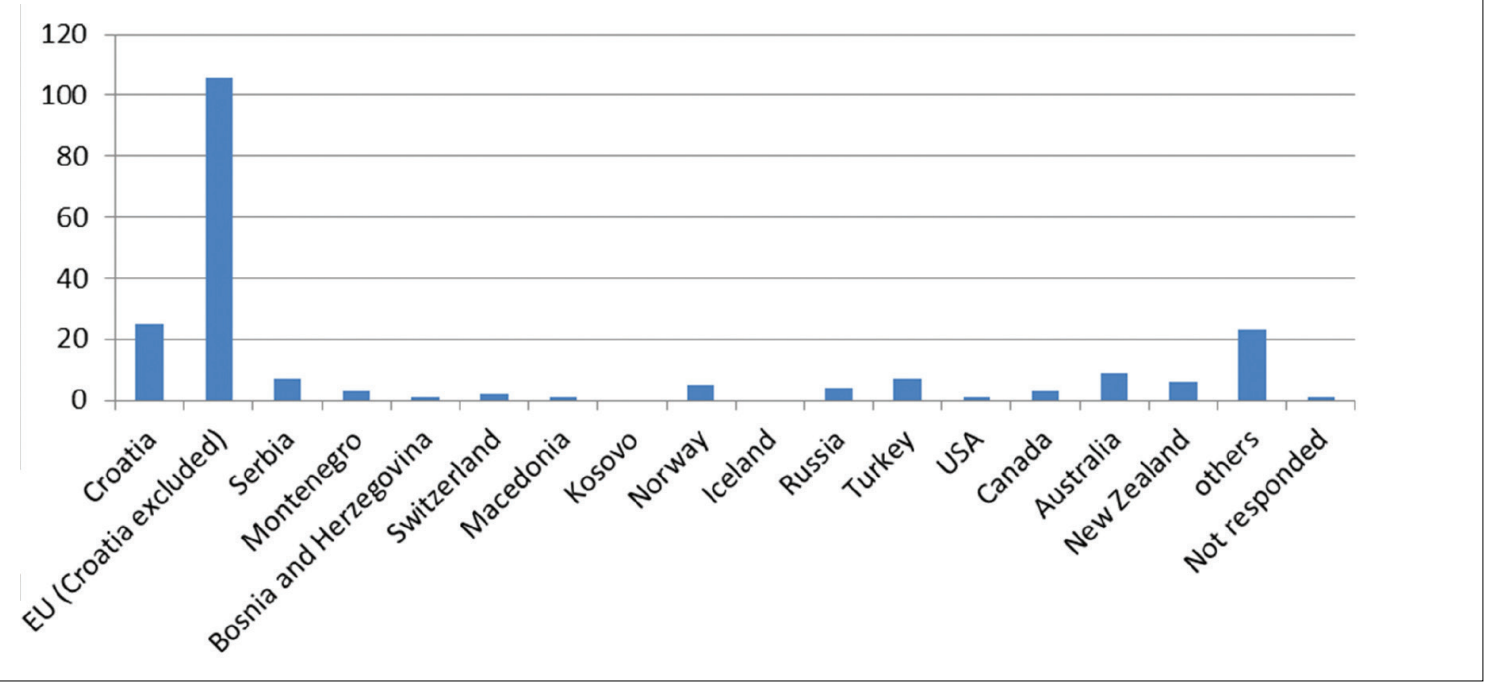

Note. Composed by the authors according to the results of research.

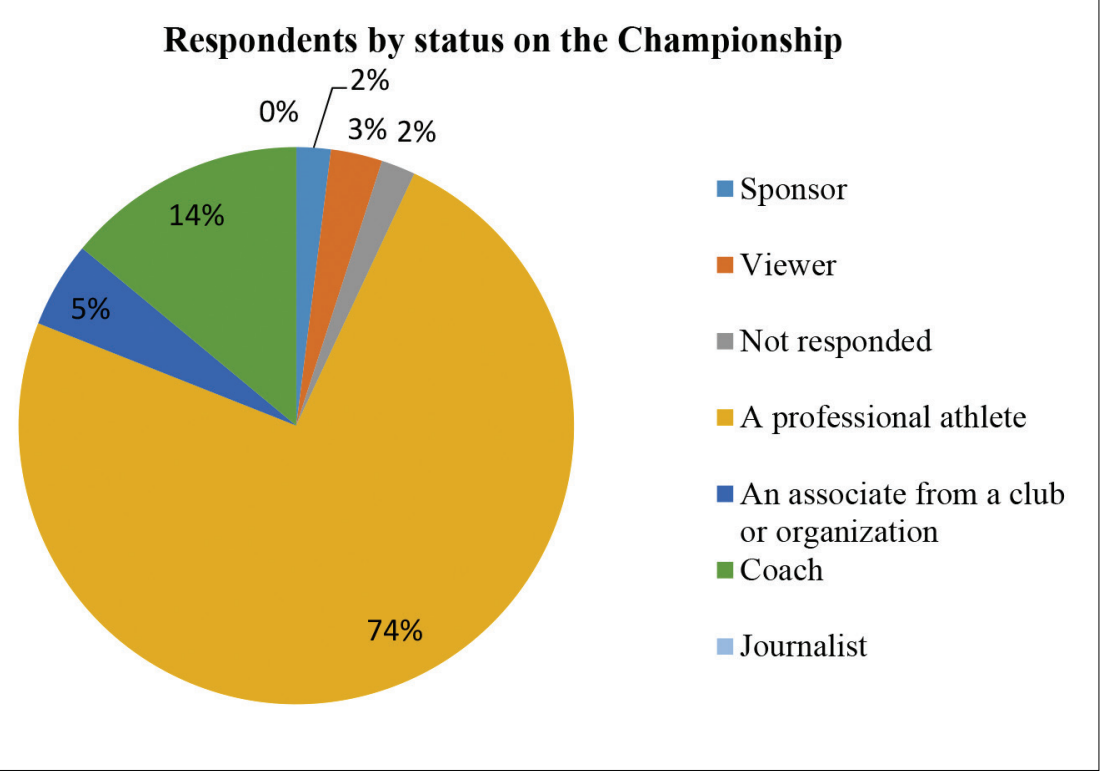

Figure 2. Respondents by status on the Championship

Note. Composed by the authors according to the results of research.

of financing their travel and accommodation expenses. Thus, five of them paid for their expenses partially by themselves and partially by clubs and organisations, whereas sponsors and the parent body clubs and organisations paid the travel expenses of others. Twenty-one respondents did not answer the above stated question.

When asked about the amount of travel and accommodation expenses in Split, the majority, 34 of them or $16.67 \%$ responded that the costs were between $€ 501$ and 899 . The same number of respondents answered that the total amount of expenses ranged between $€ 900$ and $1399 ; 11.97 \%$ of respondents or 24 of them said their expenses were from $€ 1400$ to 1799 . Travel and accommodation expenses amounted to $€ 500$ for 17 respondents. It is important to say that respondents from Split and the County did not have to reply to this particular question.

According to the results of the research, 37.25\% of respondents or 76 of them paid up to $€ 30$ per day for hospitality service, accommodation service excluded, that is, for food within and outside accommodation service; $25.98 \%$, or 53 respondents 
Figure 3. Respondents by travel and accommodation expenses in Split
Note. Composed by the authors according to the results of research.

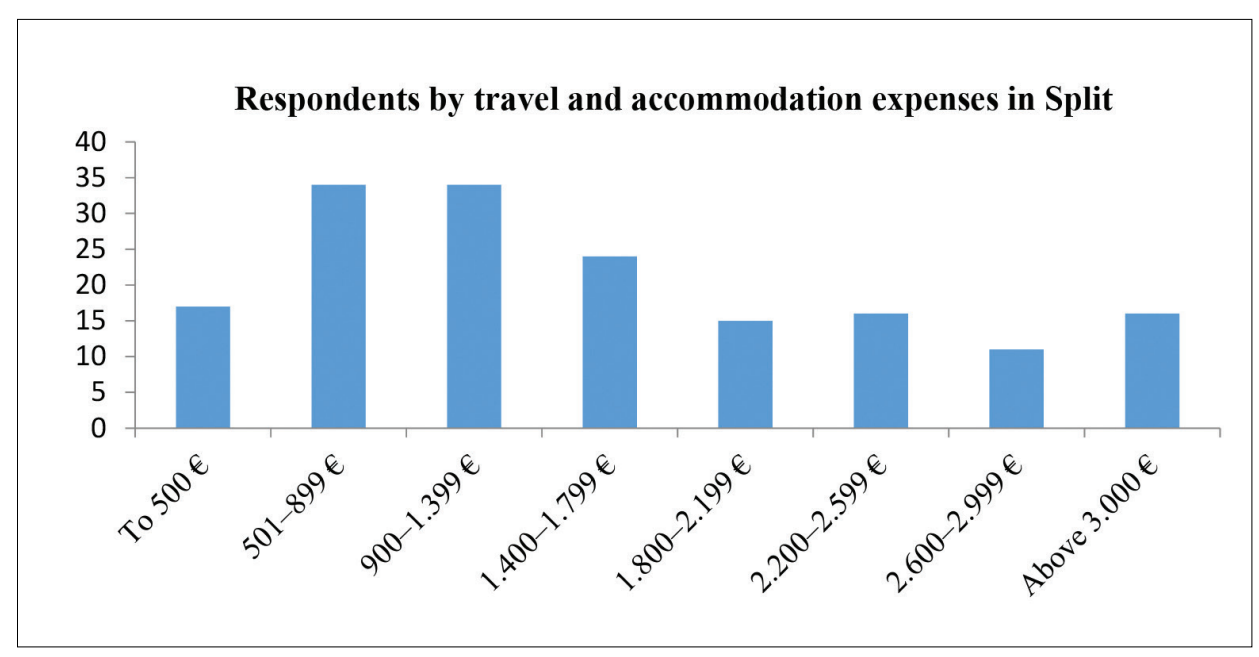

spent from $€ 31$ to 50 , whereas $14.22 \%$ spent from $€ 51$ to 70 per day. The rest of the respondents or $5.88 \%$, or 12 of them spent between $€ 71$ and 90 per day and the same segment of respondents portrays the average daily consumption from $€ 91$ to 110 . Six respondents answered that their average daily consumption was above $€ 111$, whereas, 16 respondents did not answer the question.

If we consider only the respondents who answered the survey question, it can be said that food expenses within and outside accommodation service for $40.43 \%$ of respondents amounted to $€ 30$ per day. Other respondents had expenses higher than $€ 31$.

Since an average guest in Split spends $€ 30$ for food service on a daily basis, we can confirm the hypothesis that Championship participants had higher food expenses within and outside accommodation service than the average tourist consumption on the Split level for food within and outside accommodation service.

The average daily consumption for food within and outside accommodation service was $€ 13.75$ on the County level, and $€ 14.61$ on the state level. Thus, this proves the hypothesis that Championship participants had higher food expenses within and outside accommodation service than the average tourist consumption on food within and outside accommodation service on the County level, or on the level of Croatia.

The participants were asked if they planned to visit other cultural sites such as Diocletian's
Figure 4. The average daily food expenses within and outside accommodation service

Note. Composed by the authors according to the results of research.
The average daily food expenses within and outside accommodation service

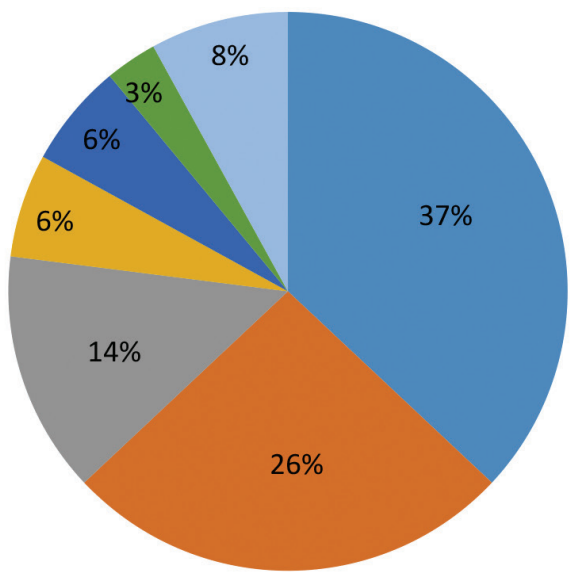

- To $30 €$

$=31-50 €$

$\varpi 51-70 €$

- $71-90 €$

-91-110€

- Above $111 €$

— Not responded 
Palace or some museums, whether they planned to visit Marjan hill on the west side of Split, sport sites such as the stadium, do shopping, go to a one-day trip, try local gastronomy. Interestingly, none of the respondents circled that option. Based on the previously said, it can be also confirmed that Championship participants wanted to visit historical and cultural sites of the destination where they stayed.

It is important to note a new study on the consumption of tourists in the Republic of Croatia, the results of which were published in 2016 (Tomas, 2016.). The results can be compared with the results of the research. According to this research, the average tourist consumption was $€ 66.36$ per day. Average daily cost of accommodation was $€ 36.22 ; 75 \%$ of the survey respondents had a stated or higher cost of accommodation per day. The average daily consumption for food within and outside accommodation service was $€ 12.18$. By comparing this data with the results of the research, it can be said that Championship participants had higher food expenses within and outside accommodation service in 2014 than the average tourist consumption for food within and outside accommodation service on country level in 2016 which is an important indicator of the importance of organizing this championship.

Financial implication of the championship. In total, 273 competitors, 62 coaches and eight referees participated in the Championship. If club representatives, journalists and com-petitors' families are added, the number of 400 Championship participants will be reached. According to the data, $10 \%$ of the Championship participants were from Split and the surroundings, therefore, it can be concluded that 360 participants had accommodation in Split. The average number of overnight stays per participant is 12 days. Taking into consideration that the sojourn tax in Split is HRK 7 per day per tourist (The Sojourn Tax Act, 2014), the Tourist Board of the city of Split collected HRK 30.240 during the Championship (assuming that all 360 participants were registered). Taking into consideration the survey results, it can be summed up that the participants, who were not from Split and the surroundings, spent at least $€ 22.680$ per day only for food within and outside accommodation service. Considering the average number of overnight stays, which is 12 per participant, it is concluded that the Championship participants spent on food within and outside accommodation service, and on hospitality service more than $€ 272.000$. The average travel expenses to Split and daily accommodation per participant amounted to $€ 1.581$ for 12 days (the average stay of the Championship participants). Based on the above said, it can be concluded that the Championship participants with the average stay of 12 days, paid $€ 569.160$ for travel and accommodation expenses. Considering the consumption of Championship participants who did not have organised accommodation on the area of Split, it can be concluded that the total consumption of all participants was more than $€ 1.000 .000$.

Also, comparing the results of the survey in 2014 with the results of average tourist spending in the Republic of Croatia (published in 2016) it can be concluded that the participants of the competition in 2014 had an average higher cost than the average tourist costs were published in 2016.

\section{CONCLUSION}

According to Beech and Chadwick (2004), in the world economy, sport has a share of 3\% of the total GDP, whereas in the European Union its share is $1.5 \%$. The impact of sport on the economy development of Croatia cannot be exactly stated since there are no reliable statistical reports. However, it is notable that sport, especially big sports events, generates high economic impact in Croatia. Unfortunately, tourism industry in Croatia is still highly seasonally oriented. Therefore, any manifestation, such as the European Sailing Championship in Split in preseason or postseason, influences the increase of the tourist offer beside the main tourist season. Participants of such competitions generally spend more than an average tourist in a destination. The results of the research have shown that during the Championship in Split participants spent more than $€ 1,000,000$, travel expenses included. Although, to a lesser extent, due to a tight schedule, participants of sport competitions still spend some time to visit a city, its culture and tradition. On their way back home, Championship participants will share their impressions with their relatives and friends, thus promoting hospitality of the city of Split, natural beauties and rich heritage, which should result that at least some of them wish to visit Split what they eventually do. 


\section{REFERENCES}

Beech, J., \& Chadwick, S. (2004.) The business of sport management. Prentice Hall.

Bartoluci, M., \& Škorić, S. (2009) Menadžment u sportu. Kineziološki fakultet, Zagreb.

Bartoluci, M., Škorić, S., \& Šindilj, M. (2013.) Modeli organizacije i kvaliteta sportsko-rekreacijskog turizma u Istri, Zbornik radova 22. ljetne škole kineziologa Republike Hrvatske "Organizacijski oblici rada u područjima edukacije, sporta, sportske rekreacije i kineziterapije", Hrvatsko kineziološko društvo, Poreč.

Butler, R., \& Pearce, D. (1995). Change in tourism. People, places, processes. Routledge, London.

Hrvatski turizam u brojkama. (2015.) Retrieved from http:// www.iztzg.hr/hr/institut/projekti/informacije/hrvatski turizam_u_brojkama

Hrvatski zavod za zapošljavanje - Godišnjak 2013. (2014). Retrieved from http://www.hzz.hr/User DocsImages/HZZ_Godisnjak_2013.pdf

Magaš, D. (2003). Management turističke organizacije $i$ destinacije. Rijeka: Sveučilište u Rijeci, Fakultet za turistički i hotelski menadžment Opatija, Adamić.
Parks, J. B., \& Quarterman, J. (2003). Contemporary sport management ( $2^{\text {nd }}$ ed.). Champaign, IL: Human Kinetics.

Stavovi i potrošnja turista u Hrvatskoj - TOMAS. (2010). Retrieved from http://www.iztzg.hr/UserFiles/ File/novosti/Tomas-Ljeto-2010-Prezentacija-HRCROTOUR-23-03-2011.pdf

Stavovi i potrošnja turista u Hrvatskoj - TOMAS. (objavljeno 2016). Retrieved from http://www.iztzg.hr/ UserFiles/Pdf/Tomas/Tomas-ljeto-2014-Prezentacija. pdf

Statistička analiza turističkog prometa u 2014 godini. (2015). Retrieved from http://www.dalmatia.hr/hr/ statistike/statisticka-analiza-turistickog-prometa-2013godine

Strategija razvoja turizma Republike Hrvatske do 2020 godine. (2015). Retrieved from http://www.mint.hr/ UserDocsImages/Strategija-turizam-2020-editfinal.pdf

UNWTO. (2003). Tourism market trends - World overview and tourism topics. Madrid.
Received on June 18, 2017

Accepted on September 05, 2017

\author{
Corresponding author Toni Miljak \\ University College of Management and Design Aspira \\ U1. Domovinskog rata 65 \\ 21000, Split \\ Croatia \\ Tel. +38521382802 \\ Email toni.miljak@aspira.hr
}

